International Journal of Social Science And Human Research

ISSN(print): 2644-0679, ISSN(online): 2644-0695

Volume 04 Issue 06 June 2021

DOI: 10.47191/ijsshr/v4-i6-31, Impact factor-5.586

Page No : 1441-1448

\title{
Improving Classroom Interaction in Reading Classes for Students at Hanoi University of Home Affairs: An Action Research
}

\author{
Luu Thi Kim Que, M.A. \\ Ha Noi University of Home Affairs, Vietnam
}

\begin{abstract}
Classroom interaction is obviously of crucial significance to English language teaching and learning. Many language teachers and researchers have made great efforts to find out ways to create interactive classroom environment that involve both teachers and learners' contributions during the whole process of teaching and learning. The study was conducted to explore classroom interaction in an English foreign language class. Questionnaire and classroom observation were used for data collecting. The results showed that the students participated more actively in reading lessons. Moreover, they developed a positive attitude towards classroom interaction and classroom interaction strategies. The findings demonstrated that increasing students' motivation, designing interactive reading tasks, and applying appropriate techniques for classroom interaction facilitated and improved classroom interaction.
\end{abstract}

KEY WORDS: classroom interaction, cooperative learning, learning techniques

\section{INTRODUCTION}

Classroom interaction is an essential part of language teaching and learning. It refers to mutual reaction repeatedly occurring between teacher and students or among students themselves in any classes.

In the field of language teaching over the last few decades, there have been controversial views about what enables classroom language learners to develop their command of a second or foreign language. However, professional experience does lead us to believe that the effectiveness of classroom language learning has something to do with classroom interaction. Therefore, many language teaching specialists attach much importance to it. Their works (Allright, 1984b; Long, 1981; Swain, 1985) to name but a few present important suggestions for learners' language development over the last few decades.

Interaction is the process whereby lessons are accomplished. If no person-to-person interaction occurs in a classroom, it will be probably unacceptable that a lesson has taken place at all. It is concluded that successful pedagogy, in any subject, necessarily involves the successful management of classroom interaction which is inevitably a co-production of teachers and learners as well. The study aimed at improving teacher-student and student-student interaction with regard to its nature and patterns in reading classes for 90 first year students in one semester at Ha Noi University of Home Affair, Viet Nam .

To achieve the above objectives, the following research questions were designed to guide the study:

- What causes students' reticence in reading classes?

- What is the students' participation when classroom interaction strategies are implemented?

- What classroom strategies are used to facilitate students' interaction?

\section{LITERATURE REVIEW}

\section{Classroom interaction}

Classroom interaction is considered a productive teaching technique. There are various ways in which the term is defined.

According to Alright (1984b: 156), classroom interaction is the process whereby classroom language learning is managed. He considers it as the fundamental fact of process of live person-to-person interaction.

Rivers (1987: 4) treats interaction as the key to language teaching for communication. She considers interaction as the facility in using a language when their attention is focused on conveying and receiving authentic messages.

As defined by Celce-Murcia (1989: 25) the term classroom interaction is "a system of giving and receiving information."

Brown (1994: 159) defines interaction as "the collaborative exchange of thoughts, feelings, or ideas between two or more people resulting in a reciprocal effect on each other." 


\section{Improving Classroom Interaction in Reading Classes for Students at Hanoi University of Home Affairs: An Action Research}

Nafrina (2007: 13) views classroom interaction as "the action performed by the teacher and the students during instruction interrelated."

As can be seen, interaction is a process collaboratively generated by two parties of participant aimed at exchanging certain messages. Classroom interaction is the interaction occurring in the context of classroom pedagogy. Thus, the participants involved in that process are teachers and learners who try to communicate with each other to achieve the goals of teaching and learning. Another definition of classroom interaction is given by Malamah-Thomas (1987: 7) who describes it as reciprocal actions. She maintains that, "the teacher acts upon the class, but the class reaction subsequently modifies his/her next action, and so on". Malamah-Thomas (1987) points out that classroom interaction is not a one-way action and reaction but a reciprocal process. Only when the participants constanly adjust their reactions to each other's previous actions can communication go on. MalamahThomas (1987: 39) illustrates the mutual reaction between the teacher and the student(s) in the following figure:

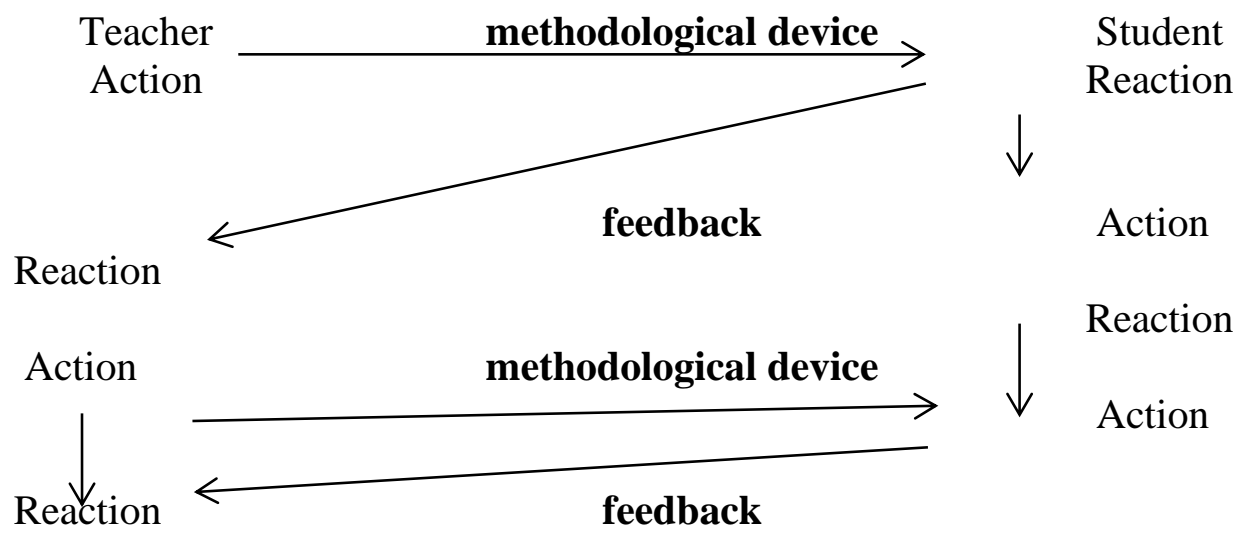

Figure 1. Mutual reactions between teacher and students (Malamah-Thomas, 1987: 39)

As shown the figure above, the teacher acts upon the student and the student reacts. The reaction, in the same way, acts upon teacher, who is turn reacts and builds into his/her subsequent action. Such interactions involved in the classroom are interpreted by some linguists in different ways.

Interaction can also be described depending on the dominant type of interaction that is taking place in the English classroom (Celce-Murcia, 1989). Accordingly, classroom interactions are different in the teacher-dominated teacher-centered, and studentcentered classrooms. In a teacher-dominated classroom, the teacher spends most of the time talking, and the student's participation is very limited. In a teacher-centered classroom, the teacher is controlling the students' participation through some classroom activities and the students have the chance to participate. Finally, in a student-centered classroom, the students can participate more actively. Besides, they can direct and develop the classroom activities by interacting among themselves and where the teacher is a facilitator of the learning process.

\section{TYPES OF CLASSROOM INTERACTION}

It is true that classroom interactions come in many shapes and forms (Van Lier, 1988) and may be in various combinations. In the classroom aiming at teaching the target language, the types of interactions often include (1) teacher speaking to the whole class; (2) teacher speaking to an individual student with the rest of the class as hearers; (3) teacher speaking to a group of students; (4) student speaking to teacher; (5) student speaking to student; (6) student speaking to group of members; (7) student speaking to the whole class.

The first two types of interaction are the most commonly occuring types in the language classroom. They are characterized by the teacher initiation, students' response and teacher follow-up pattern, referred to as the initiation-response-feedback (IRF) exchange structure.

The third type of interaction is characterized by the learner instead of the teacher to initiate the question. When this occurs, it is regarded as learner initiative. Learner initiative is common in the learner-centered classroom, but rare in the teacher-fronted classroom (i.e. classroom where the teacher interacts with the students with the whole class as the intended audience).

The fifth and sixth types - student speaking to student and student speaking to group members - are usually called pair work and group work; the latter is inevitably linked to tasks. Researchers advocating pair or group work believe that these two types of interaction can provide more opportunities for language production and collaborative work facilitates learning. 


\section{Improving Classroom Interaction in Reading Classes for Students at Hanoi University of Home Affairs: An Action Research}

Student speaking to the whole class is the seven types of interaction that mainly occurs in the student workshop or presentation.

\section{SIGNIFICANT OF CLASSROOM INTERACTION}

According to Hall \& Walsh (2002: 187), "classroom interaction is one of the primaries means by which learning is accomplished in classrooms". A good interaction will make messages transmission succeed and create a good interpersonal relationship between the teacher and students, so the students' achievement in language acquisition can be improved.

Stevick (1976, cited in Rao, 1996: 464) has argued convincingly that we may expect learning to be more effective when it more deeply involves the learner. This point has been further expanded by Moskowits (1978, cited in Rao, 1996: 464) into a whole range of activities aimed at helping learners learn through interaction with their fellow-learners, interaction that involves bringing personal value systems to the surface in the classroom. The central point established by Moskowits is that the communication of the ideas that matter to the learner is likely to aid learning by getting learners more deeply involved in what they are doing.

The opportunity for learners to negotiate meaning during meaningful interaction is of crucial importance for language learning in the classroom (Long, 1981/1983; Pica, 1987; Pica \& Doughty, 1988; Pica \& Long, 1986). Meaningful interaction is seen as genuine communication; that is, as a "two way flow or communication in which each [participant] possesses something that the other wants or needs and has a right to request and a responsibility to share" (Pica, 1987: 4) and which in turn, arises out of a social relationship in which learners and their interlocutors "see themselves as having equivalent status with regard to meeting their needs and fulfilling their obligations as conversational participants" (Pica, 1987).

The argument is further emphasized by Larsen-Freeman (1986, cited in Rao, 1996: 465) in saying that it is through interaction between speaker and listener (or reader and writer) that meaning becomes clear. In the process of language acquisition, it is insufficient for students to simply have knowledge of target language forms, structures, and functions. Students must be able to apply this knowledge in negotiating meaning. In other words, the learner must act as a negotiator of meaning if he is to become an efficient learner. During the negotiation of meaning, the learners can learn directly from each other, sharing information and knowledge they have either missed or misunderstood.

Thus, classroom interaction is one of the primary means by which learning is accomplished in classrooms. In language classrooms, it takes on an especially significant role in that it is both the medium through which learning is realized and an object of pedagogical attention. Through their interactions with each other, teachers and students construct a common body of knowledge. They also create mutual understandings of their roles and relationships, and the norms and expectations of their involvement as members in their classrooms. .

\section{TECHNIQUES FOR CLASSROOM INTERACTION}

\section{Questioning strategies}

Questioning is one of the most common techniques used by teachers and serves as the principal way in which teachers control the classroom interaction.

Teachers' questions provide necessary stepping-stones to communication. It is claimed that one of the most important keys to create an interactive language classroom is the initiation of interaction by the teacher. Through questions teachers can engage students actively in the lesson at hand, challenging their thinking and posing problems for them to consider. From a lesson perspective, a question at the beginning can be used to capture students' attention and provide a focus for the lesson. In addition, frequent and periodic questions can encourage active participation and provide opportunities in the lesson for continued student involvement. Research in this area shows student on-task behaviors are highest during teacher-led questioning sessions. Finally, at the individual level, questions can be used to draw wandering students back into the lesson or to provide an opportunity for one student to 'shine'. Researches on teacher' questioning strategies focus on teacher questions and techniques of question modification. As regard teacher questions, an abundance of studies on English as a second language/ English as a foreign language (ESL/EFL) classroom has focused on the effect of teacher questions on learners' productions of the target language and on the types of learner response.

It is agreed that the type of question asked by the teacher affects the kind of response the student produces. Lynch (1991) characterizes display questions as those questions for which the questioner knows the answer before hand and that such questions are usually asked for comprehension checks, confirmation checks or clarification requests. Odekunle (2005) amplifies further that display questions are used for getting students their knowledge of the linguistic forms of the factual content needed to respond. He also sees it as information question. On the other hand, referential questions are the ones which ask for information that the teacher does not know (Lynch, 1991). Referential questions are characterized further by Shomoossi (2004) as requiring interpretation and judgments on the part of the person to whom it is directed. It has often been observed that teachers tend to ask more display questions than referential questions (Barnes, 1969; Long \& Sato, 1983; Pica \& Long, 1986).

If the teachers just pass on information rather than encourage students to participate in classroom activities, they tend to ask 


\section{Improving Classroom Interaction in Reading Classes for Students at Hanoi University of Home Affairs: An Action Research}

referential question. However, Long \& Sato (1983) conclude that is because the teachers emphasized much more on the form and accuracy of the language, instead of the meaning of language and communication, it must be pointed out that all these researches were conducted in teacher-dominated classrooms. In student centered language classrooms, proportionately more referential questions were asked than display questions (Zhou Xing \& Zhou Yun, 2002).

Without dismissing the value of display questions in the language learning classroom, there is an ample evidence that when such questions dominate, learners' oral contributions are limited (Tsui, 1995), referential questions are thus seen as a way of enriching classroom discourse and allowing the learners to have "some degree of control over the input, which may well lead to increase motivation and more investment by the learners in the learning process" (Thompson, 1997: 101). Brock (1986, cited in Ellis, 1994) also discovered that responses to referential questions were significantly longer than those for display questions.

The second issue centered on the modification techniques of teacher's speech. Extensive literature exists on how teachers modify their speech in the classroom. The modification has been classified into several different ways (Chaudron, 1993; Holland \& Shortall, 1997). However, the current study intends to look mainly at four modifications which include repeating the question (at normal speed and slower speed), rephrasing the question, and directing the question to another student (Richards \& Lockhart, 1996: 188; Thornbury, 1996: 283; Korst, 1997: 280, Chaudron, 1993: 128).

\section{Teachers'feedback}

Another very important aspect of classroom interaction techniques is providing feedback to student responses. The kind of feedback that a teacher provides affects student learning as well. Feedback can be either positive or negative and may serve not only to let learners know how well they have performed but also to increase motivation and build a supportive classroom climate. In language classroom, feedback on a student's spoken language may be a response either to the content of what a student has produced or to the form of an utterance.

Feedback has two main distinguishable components: Correction and assessment. (Ur, 2000: 242)

- Teacher's correction: Generally, the teachers adopt the following techniques to treat students' error (Ur, 2000: 249):

$\checkmark$ Do not react at all.

$\checkmark$ Indicate there is a mistake, but does not provide any further information about what is . wrong.

$\checkmark$ Say what was wrong and provide a model of the acceptable version, or in other words, explicit correction.

$\checkmark$ Indicate something was wrong, elicit acceptable version from the learner who made the mistake (self-repair).

$\checkmark$ Indicate something was wrong, elicit acceptable version from another member of the class.

$\checkmark$ Ask the learner who made the mistake to reproduce the corrected version.

$\checkmark$ Provide or elicit an explanation of why the mistake was made and how to avoid it.

- Teacher's assessment

Assessment refers to the tools, techniques, and procedures for collecting and interpreting information about what learners can and cannot do (Nunan, 2001, cited in Xiao, 2006). In assessment, the learner is simply informed how well or badly he or she has performed. Following are lists of words and phrases that teachers may use to evaluate students' performance:

$\checkmark$ Encouragement: That's better; try it again; have another try; don't worry; go on; you've almost got it; have a guess if you don't know; you have very good pronunciation; etc.

$\checkmark$ Confirmation: Good; very good; right; you've got it; that's correct; excellent; well done; you did a very good job; no, that's wrong; not really; I'm afraid that's not quite right; etc.

\section{COOPERATIVE LEARNING TECHNIQUES}

The cooperative learning techniques refer to a set of instructional activities in which students work in groups. For group or peer involvement in language learning, some language teaching methodologists suggest the use of problem solving to promote interaction and divergent thinking. Others suggest the use of drama (improvisation, role play, simulation) and language games for group or peer involvement in classroom interaction.

Brown (1994: 81) states that cooperative learning usually involves the learner-centered characteristics. As students work together in pairs and groups, they share information and come to each other's aid. They are a 'team' whose players must work together in order to achieve goals successfully. An added connotation to the term 'cooperative', however, is its emphasis on collaborative efforts of students and teachers working together to pursue goals and objectives. Collaboration may be strictly among students, realized through pair and group work. Or it may involve student-teacher collaboration in choosing and carrying out techniques and in evaluating progress.

According to Brown (1990, cited in Loucky, n.d.), five things' students can be encouraged to do in cooperative learning groups are: solving problems together in a clam manner; cooperating rather than competing; contributing ideas to the group; helping in making good decisions; and listening carefully to learn from each others' ideas. 


\section{Improving Classroom Interaction in Reading Classes for Students at Hanoi University of Home Affairs: An Action Research}

Also, Klingner \& Vaughn (1999: 74) describes five essential characteristics of cooperative learning that reading group activities can try which include: positive independence, considerable face-to-face interaction among students, individual accountability, explicit social skills instruction, and process evaluations following each session.

Student-student interaction has a valuable role to play in foreign language learning in complement with teacher-student interaction. It provides students with a different context in which they can use the new language. Ford (1991: 45) outlines the theoretical advantages of cooperative learning in the following way:

Cooperative learning provides students with greater opportunities to: interact with each other, negotiate for meaning, work in a variety of projects that are of interest to them, participate in real-world communicative activities more frequently than in traditional teacher-fronted classrooms.

Furthermore, many researchers highlighted the value of cooperative learning in the area of language skills. They found that cooperative learning improved vocabulary and reading comprehension; and attitudes of poor readers toward reading.

Another major advantage of cooperative learning is that it frees the teacher from the usual role of instructor-corrector-controller, and allows him/her to wander freely around the class and assess the performance of individual students by noting language mistakes for future remedial work and devote more time to slower learners, in other words, to play the role of a facilitator.

\section{FINDINGS AND DISCUSSION}

\section{Research question 1}

\section{- Reading and reading materials}

Since motivation plays an essential role in students' participant in their learning process, three questions were designed to explore their opinion of interest in reading lessons and reading materials.

\begin{tabular}{|c|c|c|c|c|c|c|c|c|c|c|}
\hline & \multicolumn{10}{|c|}{ Items \& Percentage } \\
\hline & $\mathbf{A}$ & $\%$ & B & $\%$ & $\mathbf{C}$ & $\%$ & D & $\%$ & $\mathbf{E}$ & $\%$ \\
\hline $\begin{array}{l}\text { Q1. Do you like in- } \\
\text { class reading } \\
\text { lessons? }\end{array}$ & $\begin{array}{l}\text { very } \\
\text { much }\end{array}$ & 0 & fairly & 27.8 & $\begin{array}{l}\text { a } \\
\text { little }\end{array}$ & 55.6 & $\begin{array}{l}\text { not at } \\
\text { all }\end{array}$ & 16.6 & & \\
\hline $\begin{array}{l}\text { Q2. Are the topics } \\
\text { of reading lessons } \\
\text { interesting? }\end{array}$ & very & 0 & fairly & 33.3 & $\begin{array}{l}\text { a } \\
\text { little }\end{array}$ & 50 & $\begin{array}{l}\text { not at } \\
\text { all }\end{array}$ & 33.3 & & \\
\hline $\begin{array}{l}\text { Q3. Are reading } \\
\text { materials difficult? }\end{array}$ & $\begin{array}{l}\text { too } \\
\text { difficult }\end{array}$ & 11.1 & difficult & 50 & ok & 33.3 & easy & 5.5 & $\begin{array}{l}\text { too } \\
\text { easy }\end{array}$ & 0 \\
\hline
\end{tabular}

Table 1. Students' opinions of reading lessons and reading materials

The results indicate that students show little interest in reading lessons and reading materials. This is illustrated by $55.6 \%$ of "a little" in response to the first question, and none of the students like reading lessons "very much" while $16.6 \%$ is the percentage of respondents who do not like them at all. This fact can be explained by responses to the second question. Once again, no one rates reading materials as "very" interesting, "fairly" counts for $33.3 \%$ whereas up to half of the students consider the material just "a little" interesting. Regarding the difficulty of reading materials, only $33.3 \%$ and $50 \%$ of the informants mark "ok" or "fairly" respectively.

- Classroom activities

\begin{tabular}{|l|l|l|}
\hline \multirow{2}{*}{ Activities } & Percentage \\
\cline { 2 - 3 } & Most frequently occur & Least frequently occur \\
\hline A. Individual work & $100 \%$ & $0 \%$ \\
\hline B. Pair/group work & $0 \%$ & $33.3 . \%$ \\
\hline C. Whole class discussion & $0 \%$ & $66.7 \%$ \\
\hline
\end{tabular}

Table 2. Activities most and least frequently used in reading class

As can be seen from table 2, all of the students agree that individual work occurs most frequently in reading class and that the least class time is spent on pair/group work or whole class discussion. The dominance of individual work is a common phenomenon in reading class; tasks that require students to work in pairs/groups or as a whole class are rarely found there. As a consequence, there is less time and space for classroom interaction, particularly student-student interaction.

\section{- Teacher's instructions}

In order to exammine the comprehensibility of the teacher's instruction, the fifth question was used (How much do you understand your teacher's instructions in reading classes?). Responding to this question, no one assert that they fully comprehend 


\section{Improving Classroom Interaction in Reading Classes for Students at Hanoi University of Home Affairs: An Action Research}

the teacher's instructions, only $11.2 \%$ catches $70-90 \%$ of the teacher's talk, the majority of the students $(55.5 \%)$ understand just $50-70 \%$ of the teacher's instruction.

\section{- Classroom environment}

\begin{tabular}{|l|l|l|}
\hline Question 6 & Items & Percentage \\
\hline \multirow{2}{*}{$\begin{array}{l}\text { Do you feel comfortable to talk to your teacher in reading } \\
\text { classes? }\end{array}$} & very much & $11.1 \%$ \\
\cline { 2 - 3 } & fairly & $16.7 \%$ \\
\cline { 2 - 3 } & a little & $38.9 \%$ \\
\cline { 2 - 3 } & not at all & $33.3 \%$ \\
\hline
\end{tabular}

\section{Table 3. Students' feeling when talking to their teacher}

From table 3, a small proportion $(11.1 \%$ ) of the class talk to their teacher without inhibition whereas $38.9 \%$ feel a little comfortable when interacting with the teacher. A large number of the students (counts for 33.3\%) feel completely uncomfortable talking to the teacher.

Research question 3: What classroom strategies are used to facilitate student interaction? This research question is also answered basing on the results of classroom observation.

\section{$\checkmark \quad$ What patterns of classroom interaction are involved in the reading class?}

Before the intervention, the class witnessed almost only teacher-student interaction-teacher talked to either the whole class or individuals-hardly any student-student interaction could be found. The teacher primarily acted as a supplier of knowledge; she controlled classroom interaction through asking questions. The students under that circumstance acted as receivers of knowledge; they responded to the teacher's questions if asked; there were virtually no students' initiatives, that is, students did not initiate any talks neither with the teacher nor with their classmates. The dominance of teacher talk, therefore, is an indispensable consequence. After the intervention, through interactive tasks that involved pair/group work, whole class discussions, and a language learning environment that supported interaction, plenty of patterns of classroom interaction were created. As a result, students took a more active role in the process of their learning; their autonomy was promoted.

Teacher-individual student: This pattern can be easily found through the tally total of teacher asking questions (display or referential) to or praising an individual.

Teacher-whole class: This pattern is presented in different ways. At the beginning, the teacher introduces the topic, the structure of the lesson. During the lesson, the teacher praises or asks questions (display or referential) to class as a whole. At the end, the teacher and class have an extended discussion about the topic learnt which helps students to examine, evaluate and share knowledge about the subject matter. Students are provided with an atmosphere to create new ideas, view from different perspectives, and to improve their comprehension and communication skills.

Teacher-group of students: The teacher interacts with groups of students by asking questions or providing necessary language.

Notes that the teacher groups students and moves around as a facilitator when the students are working in groups.

Student-teacher: Student-teacher interaction is clearly shown. Students responded to teacher questions, and they even asked teacher questions which rarely occurred before.

Student-student and Student-group: Clear evidence of interaction among students themselves is shown in part Il-classroom activities. Before, the students listened to the teacher's instructions or read the printed instructions then did the tasks individually. In post-intervention class, assigned with information-gap reading tasks, students are divided into groups and each group get , different worksheets. Students have to work in pairs/groups to exchange ideas with and ask questions to one another to complete the reading tasks.

It is obvious that more patterns of classroom interaction are involved in the reading class during post-intervention classroom observation. Although those patterns are not evenly distributed, which means that certain patterns occur more frequently than the others, the indication is that the interaction is not monotonous. This is good to prevent the learners from getting bored, thus, increases students' motivation to participate in the lessons.

\section{$\checkmark \quad$ What are teacher's questioning strategies?}

Teacher's questioning strategies are examined from two perspectives including the distribution of display vs. referential questions and modification techniques.

Distribution of display vs. referential questions: There is a balance between display and referential questions in the whole lesson. However, the results from the table show that the distribution of display and referential questions is different in each stage of the post-intervention lesson, as illustrated as followed. 
Improving Classroom Interaction in Reading Classes for Students at Hanoi University of Home Affairs: An Action Research

\begin{tabular}{|l|l|l|l|l|}
\hline & Pre-reading & While-reading & Post-reading & Total \\
\hline Display Qs. & 7 & 28 & 5 & 40 \\
\hline Referential Qs. & 23 & 4 & 15 & 42 \\
\hline
\end{tabular}

Table 4. Distribution of display and referential questions

As shown in table 4, at the beginning, more referential questions were used to activate students' schemata as well as to motivate them. In while-reading stage, the teacher asked more display questions Which were effectively employed as a means Of checking text reading comprehension and eliciting responses from students. Post-reading activities were group work and whole class discussion in which referential questions predominated. The purpose of these questions was to expand student interaction through sharing knowledge on the topic being learnt.

Modification techniques: The teacher tried her utmost to give clear instructions and comprehensible questions so as to increase student language output. When questions were not understood the teacher commonly repeated the same questions at normal speed. The tally totals show that repetition of the questions at normal speed dominates other modification techniques. The frequent use of this technique indicated a fact that the teacher supposed that the students understood her questions, thus, she did not change the structure of her questions as well as her speed of speech. It was also claimed that the teacher constantly repeated the questions in order to draw students' attention. However, in doing so, she unintentionally did not leave time and space for students' thinking. Besides, the teacher occasionally rephrases questions by word alternation or repeats the same question at slower speed. This means that teacher's questions are more considerate for students in terms of difficulty. Moreover, the teacher seldom directs a question to another student which represents the teacher's trust in students' ability and her efforts in encouraging students' participation.

\section{$\checkmark$ What kinds of teacher's feedback are presented?}

Teacher's assessment: From the observation sheet, positive feedback was given to students and negative feedback was avoided. The teacher praised individual student, a group of students, and the whole class, and no criticism was found. The teacher believed that positive feedback is of significance in establishing good relationship between teacher-students as well as friendly atmosphere during the whole process of teaching and learning. This can, in turn, motivate students in learning reading and stimulate their interaction in reading classes.

Error correction: As regards error treatment, two most frequently used techniques were ignoring errors and asking students to fry again. The former was used most at pre- and post-reading stages when the lesson was focused on content rather than form. In doing so, the teacher wanted to ensure smooth communicative interaction and to avoid demotivating students as well. The frequent use of the latter reflected that the teacher highly appreciated students' independence in learning through self-correcting mistakes.

\section{CONCLUSION}

From the data analysis, it was found that the implementation of classroom interaction strategies had positive effects on students' participation. They became more active in reading lessons. More students volunteered to respond to the teacher's questions, they even asked questions to initiate talks in class. The interactions were more diverse; different types of classroom interaction existed in the reading class. What conditioned classroom interaction were relevant reading materials and opportunities for students to interact. Moreover, the classroom interaction occurred as mutual reactions between the teacher and students or among the students themselves mostly through the cycles of asking and answering questions. Therefore, the teacher's questions and feedback, especially her treatment of errors, played an important role. There were also significant changes in students' perceptions of reading lessons and classroom interaction in reading lessons. They were more motivated to learn reading. In addition, the students realized the benefits of classroom interaction through classroom activities. Most of them agreed to be put in a language learning environment which supported their interaction and participation in the teaching and learning process.

The study was intended to investigate classroom interaction and techniques for improving classroom interaction in reading classes. In reality, owing to the realization of these techniques and the training program into reading classes, the classroom interaction, to some extent, has been improved. This study actually provided supportive evidence that classroom interaction and classroom interaction strategies had facilitative impact on students' interaction and participation. EFL teacher, thus, should stimulate learners' interests and provide as many opportunities as possible for classroom interaction, especially student-student interaction by implementing various classroom interaction tasks.

\section{REFERENCES}

1) Allwright, D. (1984b). Why don't learner learn what teachers teach? The interaction hypothesis. In S. Little (Ed.). Language learning in formal and informal contexts, (pp.3-18). Dublin: BAAL/IRAAL. 


\section{Improving Classroom Interaction in Reading Classes for Students at Hanoi University of Home Affairs: An Action Research}

2) Barnes, D. (1969). Language in the secondary classroom. In D. Barners, J. Britton \& H. Roses (Eds.). Language, the learner, and the school (pp. 11-77). Harmondsworth, UK: Penguin.

3) Brown, H. D. (1 994). Teaching by principles: An interactive approach to language pedagogy. New Jersey: Prentice Hall Regents.

4) Celce-Murcia, M. (1989). Interaction and communication in the TESOL classroom. A Forum Anthology, 4, $25-31$.

5) Chaudron, C. (1993). Second language classrooms: Research on teaching and learning. Cambridge: Cambridge University Press.

6) Ellis, R, (1994). The study of second language acquisition. Oxford: Oxford University Press.

7) Ford, E. (1991). Criteria for developing an observation scheme for cooperative language learning. Modern Language Journal, 48(1), 45-63.

8) Hill. J. K., \& Walsh, M. (2002). Teacher-student interaction and language learning. Annual Review of Applied Linguistics, 22, 186-203.

9) Holland, R., \& Shortall, T. (1997). Classroom research and research methods. Birmingham: The Center for English Language Studies.

10) Klingner, J. K., \& Vaughn, S. (1999). The helping behaviors of fifth graders while using collaborative strategic reading during ESL content classes. TESOL Quarterly, 34(1 ), 69-98.

11) Korst, T. (1997). Answer, please answer! A perspective on Japanese university student silent response to questions. Japanese Association for Language Teaching Journal, 19(2), 279-291.

12) Long, M. H. (1981). Input, Interaction and second language acquisition. In H. Wintiz (Ed.). Native language and foreign language acquisition (pp. 259-278). New York: Annals of the New York Academy of Science.

13) Long, M. (1983). Native speaker/ non-native speaker conversation and the negotiation of comprehensible input. Applied Linguistics, 4, 126-141.

14) Long, M. H. \& Sato, C. J. (1983). Classroom foreign talk discourse: Forms and functions of teachers' questions. TESOL Quarterly.

15) Loucky, J. P. (2005). Combining Intensive and Extensive reading strategies with cooperative and communicative learning activities. Asia, 3(2).

16) Lynch, T. (1991). Questioning roles in the classroom. ELT Journal, 43(3), 201-210.

17) Malamath-Thomas, A. (1987). Classroom interaction. Oxford: Oxford University Press.

18) Nafrina, J. K. (2007). The teacher and learner talk in the classroom interaction of grade viii: A SMP N 2 cepiring kendal. Semarang State University.

19) Odekunle, O. A. (2005). Patterns of classroom interaction in comprehension classes in selected secondary schools in Ibadan. University of Ibadan, Nigeria.

20) Pica, T. \& Long, M. H. (1986). The classroom linguistic and conversational performance of experienced and inexperienced teachers. In R., Day (Ed.), Talking to learn. Rowley, Massachusetts: Newbury House.

21) Pica, T. \& Doughty, C. (1988). Variations in classroom interaction as function of participation patter task. In J. Fine (Ed.). Second language discourse: A textbook of current research. Norwood, New Jersey: Ablex Publishing Corporation.

22) Rao, Z. (1996). Reconciling communicative approaches to the teaching of English with traditional Chinese methods. Research in the Teaching of English, 30(4), 458-471.

23) Richards, J. C. \& Lockart, C. (1996). Reflective teaching in second language classroom. Cambridge: Cambridge University Press.

24) Rivers, W. M. (Ed.). (1987). Interactive language teaching. Cambridge: Cambridge University Press.

25) Shomoossi, N. (2004). The effects of teachers' questioning behavior on EFL classroom interaction. Retrieved September 9, 2020 from

26) www.readingmatrix.com/articles/shomoossi/articlevolum4. number2.

27) Thompson, G. (1997). Training teachers to ask questions. ELT Journal, 51, 99-105.

28) Thornbury, S. (1996). Teachers research teacher talk. ELT Journal, 50(4), 279-289.

29) Tsui, A.B.M. (1995). Introducing classroom interaction. London: Penguin English.

30) Ur, P. (2000). A course in language teaching: Practice and theory. Cambridge: Cambridge University Press.

31) Xiao, Y. (2006). Teacher talk and EFL in university classroom. Chongqing Normal University \& Yangtze Normal University.

32) Zhou, X. Zhou, Y. (2002). Study of teacher talk in English language classrooms at a university level. Foreign Language Teaching and Research, 34(1), 59-68. 